\title{
Ficus Thonnigii Enhances Exploratory/Locomotor Activities in Mice
}

\author{
Aduema $\mathrm{W}^{* 1}$, Vidonna $\mathrm{WB}^{2}$, Amah $\mathrm{AK}^{3}$ and Akunneh Wariso $\mathrm{C}^{4}$ \\ ${ }^{1}$ Department of Medical Physiology, PAMO, University of Medical Sciences, Nigeria \\ ${ }^{2}$ Department of Human Anatomy, Gregory University, Nigeria \\ ${ }^{3}$ Department of Medical Physiology, Imo State University, Nigeria \\ ${ }^{4}$ Department of Human Physiology, Abia State University, Nigeria
}

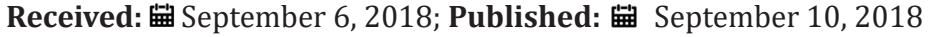

*Corresponding author: Aduema wadioni, Department of Medical Physiology, PAMO, University of Medical Sciences, Port Harcourt, Rivers State, Nigeria

\begin{abstract}
Ficus thonningii plant has been reported to be used for the treatment of various ailments, such as stomach ache, pain diarrhea, etc. Therefore, the present study was carried out to investigate its effect on exploratory/locomotor activities of the ethanol extract of the leaves of the plant Exploration/locomotor behavior were assessed using the open field maze and the light/dark transition box tests. Animals were divided into three groups containing 10 mice each. Group A served as the control which was administered $1 \mathrm{ml}$ of distilled water, while Group B and Group C which were the low and high dose groups, were administered $10 \mathrm{mg} / \mathrm{kg}$ and $25 \mathrm{mg} / \mathrm{kg}$ of the plant extract for two weeks period. Prior to the administration of the extract and commencement of the experiment, the $\mathrm{LD}_{50}$ of the plant was determined. The result showed a dose dependent increase in the line crosses and center square entries $(\mathrm{p}<0.01)$. The frequency of stretch attend posture and duration of freezing were also significantly higher $(\mathrm{p}<0.05 ; \mathrm{p}<0.001)$ compared to control. This means that the mice were more exploratory in behavior and less fearful/anxious. Similar results were obtained in the light /dark transition box test, were the line crosses and stretch attend posture also showed that the low and high dose statistically higher compared to control $(\mathrm{p}<0.01 ; \mathrm{p}<0.05)$. The frequency of transition was also increased $(\mathrm{p}<0.05 ; \mathrm{p}<0.01)$. In conclusion, ethanol extract of Ficus thonningii increase exploration/ locomotor activities in mice.
\end{abstract}

\section{Introduction}

Ficus thonningii is a traditionally important plant species with both nutritional and therapeutic benefits. Commonly known as the common wild. F. thonningii leaves are alternate and dark green whilst the fruits which are about 10-20 mm in diameter are usually yellow, turning pinkish when ripe [1]. The tree is popular for its medicinal properties and is used in the treatment of various disease conditions. F. thonningii leaves are a good source of protein [2]. Protein content in F. thonningii leaves ranges between 18.7$20.5 \mathrm{~g} / 100 \mathrm{~g}$ dry matter (DM) [2]. This makes them a useful dietary source of essential and non-essential amino acids. F. thonningii leaves therefore have the potential to be used to militate against protein deficiency diseases in children particularly in drought prone areas. The leaves are also good sources of micronutrients. They have an ash content of up to $17.34 \% \mathrm{w} / \mathrm{w}$ [3]. F. thonningii also has high levels of calcium, $180.05 \mathrm{mg} / 100 \mathrm{~g}$ dry weight [4] as compared to that in bovine milk $(118 \mathrm{mg} / 100 \mathrm{ml})$. Potassium levels range between 0.91 and $1.25 \mathrm{~g} / 100 \mathrm{~g}$ dry weight and magnesium levels between 260 and $357.2 \mathrm{mg} / 100 \mathrm{~g}$ dry weight [4,5].

F. thonningii leaves have also been shown to contain a high crude fibre content which reaches up to $19.41 \% \mathrm{w} / \mathrm{w}$. Crude fibre is important, particularly in ruminant nutrition, for the production of volatile fatty acids which account for about $80 \%$ of the metabolic energy requirements [5] Owing to its good nutrient profile, F. thonningii is used as forage for ruminants [6] and rabbits. A comparative study done to evaluate the utilisation of $F$. thonningii and Mangifera indica (mango) leaves by rabbits showed that rabbits on $F$. thonningii leaves had a significantly higher average body mass compared to those on Mangifera indica leaves. African ethnic groups have reported the use of $F$ thonningii in cuisine. The evergreen leaves are cooked as a vegetable by the Igede and Fulani of Nigeria [7], and the Senegalese [8]. The leaves are similarly used in Angola, Sudan, Benin and Ethiopia [9,10]. In addition to its widespread use as a food supplement and vegetable, F. thonningii is extensively used as medicine for treating disease, maintaining health and restoring tissue functioning and vitality. Ficus thonningii which are found in the tropics, including Nigeria. Since it is not known in our environment and people have little knowledge of its effect on exploration/locomotion. Therefore, this research work tends to evaluate its effect on the above neurobehavioral parameters. 


\section{Materials and Methods}

\section{Experimental Animals}

Thirty adult male mice weighing between 18-20g were obtained from the animal house of Pharmacology Department, Michael Okpara University, Umuidike and transported to the Department of Physiology, Abia State, University, Uturu. They were fed vital feed and given clean drinking water for 2 weeks before the commencement of the research work.

\section{Collection and Preparation of Ficus thonningii Extract}

Fresh leaves of $\mathrm{F}$. thonningii were bought from a local samaru market in Zaria, Kaduna state in large quantity. The leaves were washed in water to clean them of debris and then allowed to dry. The air -dried leaves $(200 \mathrm{~g}$ ) of $F$. thoningii was pulverized and soaked in ethanol [11] for $72 \mathrm{hrs}$.The solution was filtered, and the filtrate concentrated with a rotary evaporator to give a semisolid residue. This product was kept in the refrigerator for further use. The dried extract was then subsequently reconstituted in distilled water at appropriate concentration for the experiments.

\section{Preparation and Treatment of the Animals}

Prior to the experiment, the $\mathrm{LD}_{50}$ of the plant was determined. The animals were housed in the animal house of Department of Physiology, Abia State University, Uturu. The animals were kept in cages in a well-ventilated space under normal temperature and 12/12 hours light/dark cycle. The three groups of animals were fed with the feed/diet designated for them. The control group (Group 1) was administered distilled water ( $1 \mathrm{ml})$ while, Group 2 and Group 3 received $10 \mathrm{mg} / \mathrm{kg}$ and $25 \mathrm{mg} / \mathrm{kg}$ of the extract for a period of two weeks. All administration was via oral route.

\section{Experimental Protocol}

The animals were randomly divided into three groups of 10 mice each: Control, low dose and high dose groups. At the end of the 2 weeks of administration, the apparatus meant for the experiment were setup. The video camera was mounted at the position to cover the experiment. The animals reposition in the room to give room for the experimental activities. The apparatus was:

\section{a) Open field maze}

b) Light and dark transition box.

\section{Procedure in the Open field Mace}

Each mouse was place in the center square of the open field maze and allowed to explore the apparatus for a total of 5 minutes. After each 5 minutes for a mouse, the open field maze was cleared with $70 \%$ ethyl alcohol and permitted to dry between tests. This was to eliminate olfactory stimuli. Mice in all the groups followed the same procedure. The open field maze was used to measuring the locomotor activity of the mice as it has a large center arena. This procedure was based on that of [12].

\section{Behaviors Scored}

The behaviors scored (12) included:

Line Crossing: Frequency with which the mice crossed one of the grid lines with all four paws.
Centre Square Entries: Frequency with which the mice crossed one of the red lines with all four paws into the central square.

Centre Square Duration: Amount of time the mice spent in the central square.

Rearing: (aka rearing center) frequency with which the mice stood on their hind legs in the maze without aid of a wall.

Stretch Attend Postures: Frequency with which the animal demonstrated forward. Freezing duration and frequency with which the mouse was completely stationary.

\section{Procedure in the Light and Dark Transition Box}

Mice were carried into the test room in their home cages. Each mouse was picked by the base of its tail and placed in the center of the light compartment facing the door and allowed to explore the apparatus for 5 minutes. The mouse behavior was scored within the period and the maze clean with a solution of $70 \%$ ethyl alcohol and then allowed to dry between tests. The procedure was based on that of Costal et al. [13].

\section{Behaviors to be Scored Included the Following}

Transition: Number of times the animal passes in or out of the light and dark chambers with all four paws.

Stretch Attends Posture: Frequency with which the animal demonstrates forward elongation of the head and shoulders followed by retraction to original position.

Line Crossing: Frequency with which the mice crossed one of the grid lines with all four paws.

\section{Statistical Analysis}

Data collected during the study were expressed as Mean \pm SEM. Analysis of variance (ANOVA) and student $t$-test was used for analysis. Values of $\mathrm{p}<0.001 \& \mathrm{p}<0.05$ were regarded as significant. Also, a post hoc test $(<\mathrm{SD})$ was carried out. Statistical analysis was done with the aid of computer software SPSS and Excel from Window XP (Brain Series, China).

\section{Results}

\section{Behaviors scored in the Open field maze}

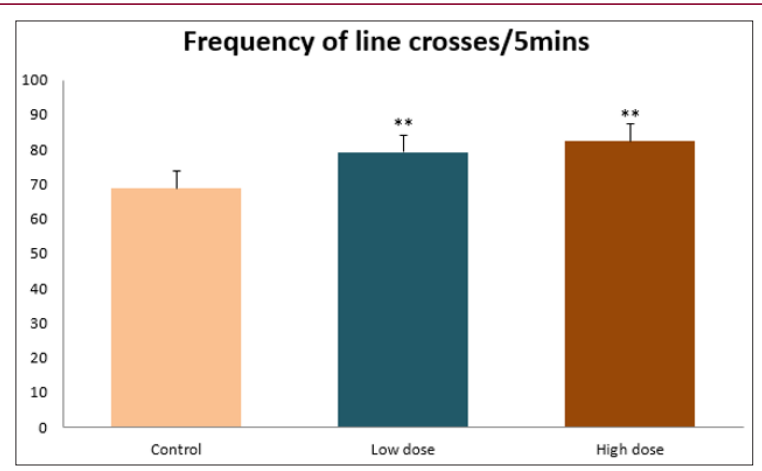

Figure 1: Comparison of the frequency of line crosses in the open field maze test in mice following administration of graded doses of $F$. thoningii. Values are expressed as mean \pm SEM, $\mathrm{n}=10$.

Note: ${ }^{* *} \mathrm{p}<0.01$ vs. control. 
Line Crosses: The number of lines crossed by mice within five minutes of exposure to the open field maze administered control, low and high dose diets were $68.7 \pm 11.97 ; 79.2 \pm 10.32$ and $82.4 \pm 7.51$ respectively. Those mice administered low and high dose of the extract were seen to be significantly higher $(p<0.01)$ than the control (Figure 1).

Centre Square Entry: The values of the centre entry following administration for control, low and high dose were16.4 \pm 2.20 ; $28.88 \pm 2.84$ and $30.00 \pm 2.24$ respectively. It was observed that the frequency of centre square entry was statistically higher $(\mathrm{p}<0.01)$ compared to control (Figure 2).

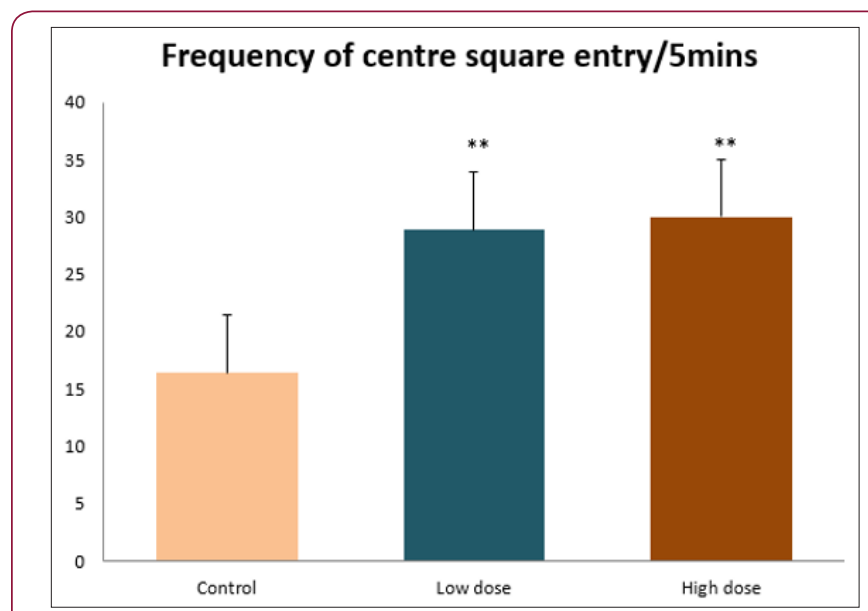

Figure 2: Comparison of centre square entry in the open field maze test in mice following administration of graded doses of F.thoningii. Values are expressed as mean \pm SEM, $\mathrm{n}=10$.

Note: ${ }^{* *} \mathrm{p}<0.01$ vs. control.

Stretch Attends Posture: The stretch attends posture values were $22 \pm 2.9 ; 19.8 \pm 1.13$ and $18.8 \pm 0.13$ for mice administered control, low and high dose of the extract. The low and high dose groups were significantly lower $(\mathrm{p}<0.05)$ compared to control (Figures 3-7).

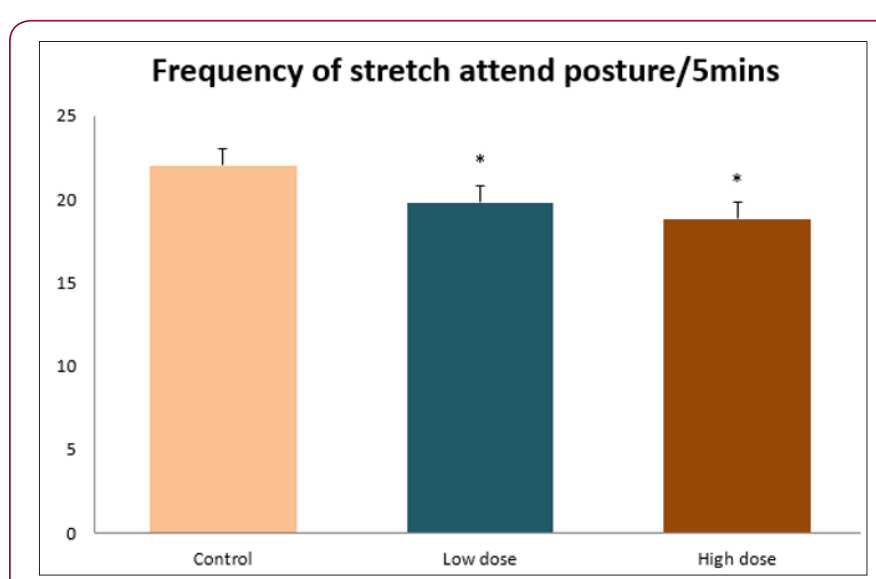

Figure 3: Comparison of the frequency of stretch attends posture in the open field maze test in mice following administration of graded doses of F.thonningii. Values are expressed as mean $\pm \mathrm{SEM}, \mathrm{n}=10$. ${ }^{*} \mathrm{p}<0.05$ vs. control.

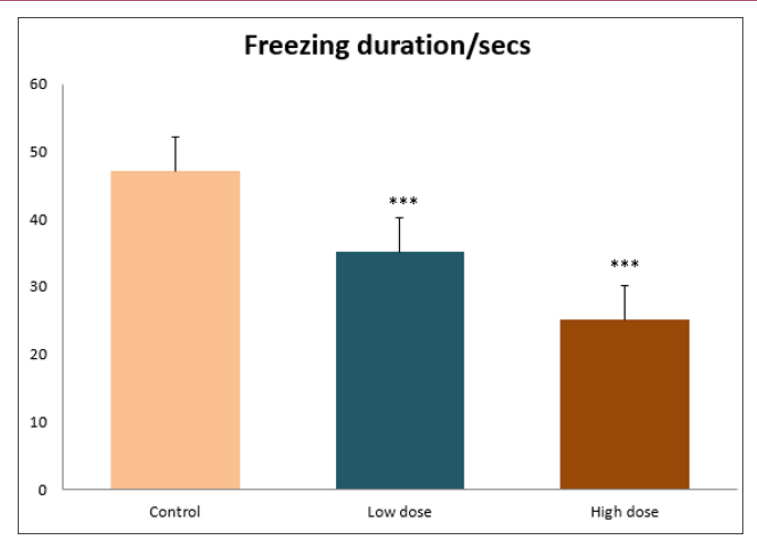

Figure 4: Comparison of the freezing duration in the open field maze test in mice following administration of graded doses of F.thonningii. Values are expressed as mean \pm $\mathrm{SEM}, \mathrm{n}=10$.

Note: ${ }^{* *} \mathrm{p}<0.001$ vs. control.

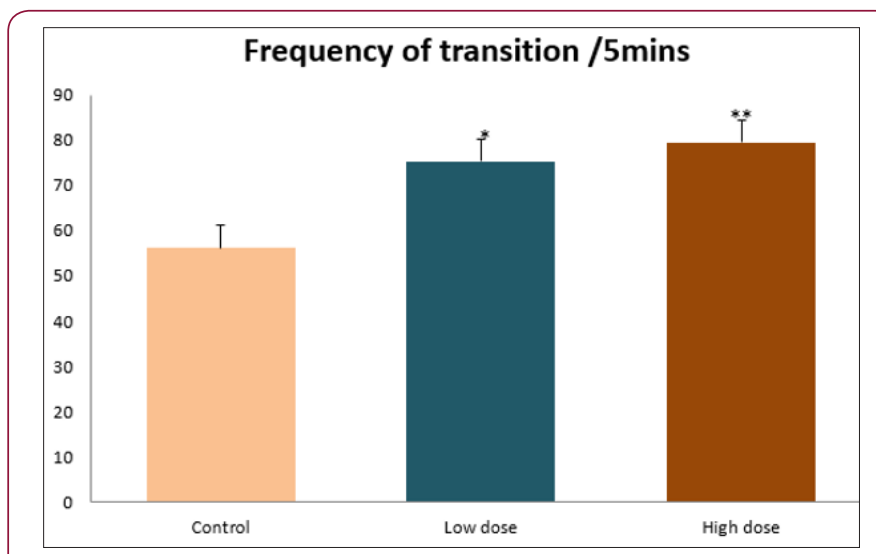

Figure 5: Comparison of the frequency of transition in the open field maze test in mice following administration of graded doses of $F$. thonningii. Values are expressed as mean \pm SEM, $\mathrm{n}=10$.

Note: * $\mathrm{p}<0.05$ vs. control; ${ }^{* *} \mathrm{p}<0.01$ vs. control.

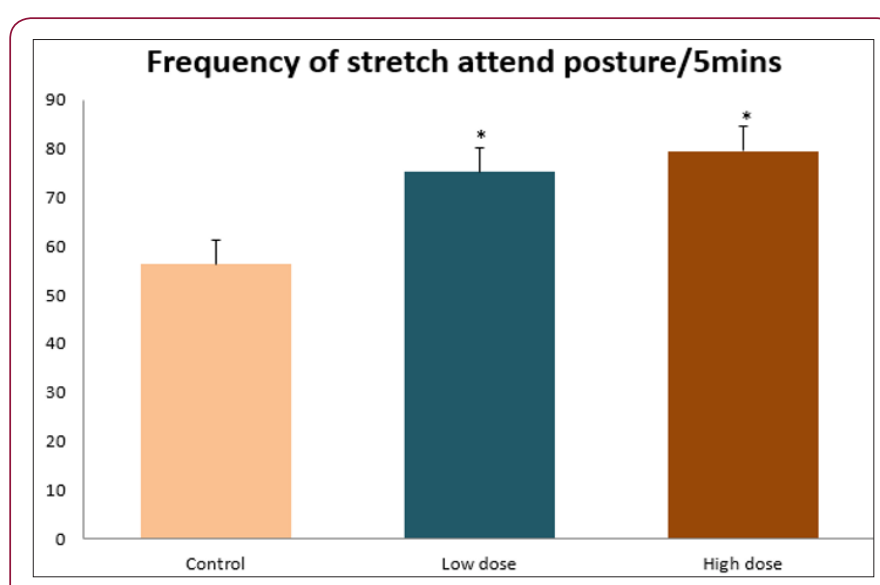

Figure 6: Comparison of the frequency of SAP in the light/ dark box in mice following administration of graded doses of F.thoningii. Values are expressed as mean \pm SEM, $\mathrm{n}=10$.

Note: ${ }^{*} \mathrm{p}<0.01$ vs. control. 


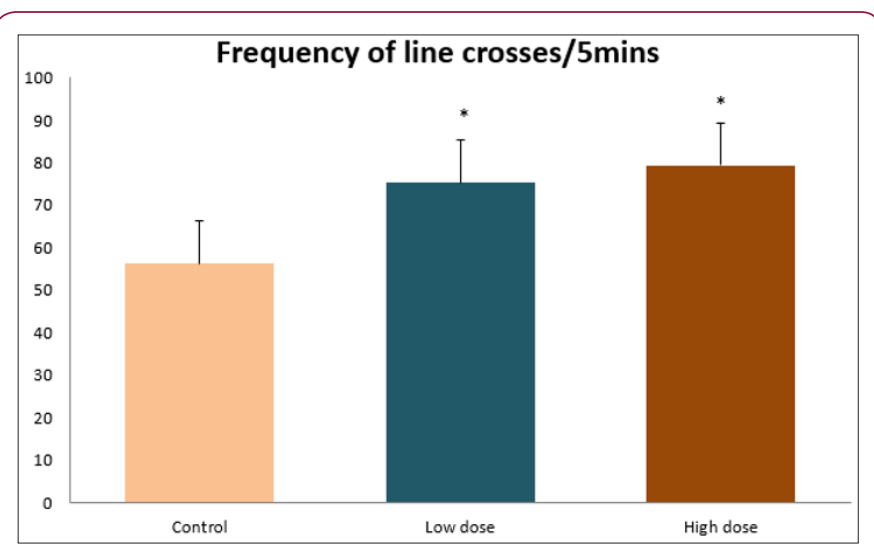

Figure 7: Comparison of the line crosses in the light/dark box in mice following administration of graded doses of $\mathrm{F}$. thonningii. Values are expressed as mean \pm SEM, $n=10$.

Note: ${ }^{*} \mathrm{p}<0.05$ vs. control.

Freezing Duration: The values for the freezing duration among the experimental groups were 47.11 \pm 2.44 (control),35.12 \pm 3.33 (low dose) and 25.10 \pm 5.12 (high dose). The result showed that the low and high dose groups were significantly lower $(\mathrm{p}<0.001)$ compared to the control group.

\section{Behaviors Scored in the Light/Dark Box}

Transition Frequency: The frequency of transition for the low and high dose groups were $43.79 \pm 5.61$ and $34.82 \pm 5.14 / 5 \mathrm{~min}$, which was significantly higher $(\mathrm{p}<0.01 ; \mathrm{p}<0.05)$ compared to control which was $22,82 \pm 5.84 / 5 \mathrm{~min}$.

Stretch Attends Posture: The stretch attends posture frequency for the high and low dose groups were 15.6 \pm 3.02 and $19.23 \pm 2.3 / 5 \mathrm{~min}$ which were significantly lower $(\mathrm{p}<0.05)$ compared to control which was $27.4 \pm 1.80 / 5 \mathrm{~min}$.

Line Crosses: The values for the high and low dose groups were $79.44 \pm 7.71$ and $75.23 \pm 11.85 / 5 \mathrm{~min}$, which were significantly higher $(\mathrm{p}<0.05)$ compared to control which was $56.22 \pm 6.17 / 5 \mathrm{~min}$.

\section{Discussion}

The aim of the study was to investigate the effect of acute administration of Ficus thonningii on exploration and locomotor activity in mice. The open field maze and the light-dark transition box test were used to assess these behaviors. They provide simultaneous measures for locomotion and exploration in addition to anxiety [14]. In the open field test, a high frequency of line crossing and rearing behaviors, indicates increased locomotion and exploration. The result of our study showed that behaviors such as the frequency of line crosses and the centre square entry were significantly higher in the low and high dose groups of mice compared to the control, indicating a higher exploration and locomotor activity. The frequency of stretch attend posture (SAP), which is a risk assessment behavior where rodents demonstrate forward elongation of the head and shoulder and retract back into its original position was significantly lower in the low and high dose groups compared to the control, which implies that the low and high dose group of mice were less hesitant to explore their novel environment when compared to the control.
This indicates enhanced exploratory/locomotor activity. The freezing duration which refers to the time spent by the mice in a stationary position was observed to be significantly lower in the low and high dose groups of mice when compared to the control. This means that the treated mice spent less time standing in a stationary position. Thus, indicating a higher exploratory/ locomotor activity in the treated groups of mice. In the light/dark box test, a similar result, like that of the open field was obtained. The frequency of line crosses and the frequency of transition in the low and high dose groups were significantly higher compared to the control. Furthermore, the frequency of stretch attend posture was significantly lower for the low and high dose groups compared to control. This also indicates a higher exploration/locomotor activity. Locomotion is controlled by the central pattern generator of the spinal cord. It is therefore conceivable that motor activity enhancement may be starting to manifest at dose dependent level. Perhaps, the plant Ficus thonningii may be responsible for the effect by increasing motivation to walk, thus stimulating the motor system.

\section{Conclusion}

In conclusion, acute administration of the plant extract at different dosage causes increased exploration/locomotor activity in mice. This may be as a result of the stimulating effect of Ficus thonningii on the motor system such as the cerebellum.

\section{References}

1. Schmidt E, Lotter M, Mc Cleland W (2002) Trees and shrubs of Mpumalanga and Kruger National Park. Jacana, South Africa pp. 80.

2. Tegbe TSB, Adeyinka IA, Baye KD, Alawa JP (2006) Evaluation of feeding graded levels of dried and milled Ficus thonningii leaves on growth performance, carcass characteristics and organ of weaner rabbits. Pakistan J Nutr 5: 548-550.

3. Alawa JP, Jokthan GE, Akut K (2002) Ethnoveterinary medical practice for ruminants in the sub-humid zone of the northern Nigeria. Prev Vet M 54: 79-90.

4. Titanji VPK, Zofou D, Ngemenya MN (2008) The antimalarial potential of medicinal plants used for the treatment of malaria in Cameroonian folk medicine. AJTCAM 5: 302-321.

5. Bamikole MA, Ikhatua UJ, Arigbede MO, Babayemi OJ, Etela I (2004) An evaluation of the acceptability as forage, of some nutritive nadantinutritive components of the dry matter degradation profiles of five species of Ficus. Trop Anim Health Prod 36: 157-167.

6. Mali RG, Mehta AA (2007) A review on anthelmintic plants. Nat Prod Rad 7: 466-475.

7. Igoli JO, Tor Anyin TA, Usman SS, Oluma HOA, Igoli NP (2002) Folk medicines of the Beneu valley of Nigeria. In Singh VK, Govil JN, Hashim $S$, Sing G (Eds.). Recent progress in Medicinal plants, Ethnomedicine and Pharmacognosy.Science Technology Publishers, Raleigh, North California, USA, 7: pp 327-338.

8. Gueye M, Diouf M (2007) Traditional leafy vegetables in Senegal Diversity and medicinal uses. AJTCAM 4: 469-475.

9. Danthu P, Solovier P, Gaye A, Sarr A, Seck M, et al. (2002) Vegetative propagation of some West African species by cuttings. Agroforestry Systems 55: 57-63.

10. Acamovic T, Brooker JD (2005) Biochemistry of plant secondary metabolites and their effects in animals. Proceedings of the Nutrition Society 64: 403-412. 
11. Walsh RN, Cummins RA (1995) The open field test a critical review. Psychological Bulletin 83: 482-504.

12. Brown RE, Corey SC, Moore AK (1999) Differences in measures of exploration and fear in $\mathrm{MHC}$ congenic $\mathrm{C} 57 \mathrm{BL} / 6 \mathrm{~J}$ and $\mathrm{B} 6-\mathrm{H}-2 \mathrm{~K}$ mice. Behavior Genetics 29: 263-271.

ISSN: 2574-1241

DOI: 10.26717/BJSTR.2018.08.001718

Aduema W. Biomed J Sci \& Tech Res

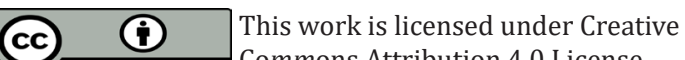

Submission Link: https://biomedres.us/submit-manuscript.php
13. Costall B, Jones BJ, Kelly ME, Naylor RJ, Tomkins DM (1989) Exploration of mice in a black and white test box: Validation as a model of anxiety. Pharmacology, Biochemistry and Behavior 32(3): 777-785.

14. Nilson RA (1998) Qualitative and Quantitative Risk Assessment of Snuff Dipping. Regulatory Toxicology and Pharmacology 28(1): 17-26.

$\begin{array}{ll}\text { BIOMEDICAL } & \text { Assets of Publishing with us } \\ \text { RESEARCHES } & \text { - Global archiving of articles } \\ \text { - Immediate, unrestricted online access }\end{array}$

